DOI: https://doi.org/10.32839/2304-5809/2020-12-88-27

УДК 339.52

Ковальчук Ю.А., Гонтарева I.B.

Харківський національний університет імені В.Н. Каразіна

\title{
МОТИВАЦІЯ МЕНЕДЖЕРІВ ПІДПРИЕМСТВА, ЩО ЗДІЙСНЮЄ ЗОВНІШНЬОЕКОНОМІЧНУ ДІЯЛЬНІСТЬ
}

\begin{abstract}
Анотація. У статті досліджено проблематику мотивації менеджерів підприємств, що здійснюють зовнішньоекономічну діяльність. Проаналізовано специфіку функцій управління зовнішньоекономічною діяльністю для поглибленого розуміння основних потреб працівників; від задоволення цих потреб залежить стимулювання робочого процесу та підвищення ефективності. Дано оцінку системам мотивації, які $є$ конфліктогенними або такими, що не результативними та визначено причини їх неефективності. Акцентовано увагу на основних фракторах ефективності системи мотивації. Визначено основні заходи, необхідні для підвищення результативності системи стимулювання роботи та дано оцінку можливим результатам їх впровадження. Досліджено види та моделі системи мотивації персоналу відповідно до їх характеру та цілей.
\end{abstract}

Ключові слова: мотивація, система мотивації, зовнішньоекономічна діяльність, управління персоналом, ерективність.

Kovalchuk Yurii, Hontareva Iryna

V.N. Karazin Kharkov National University

\section{MOTIVATION OF MANAGERS OF AN ENTERPRISE, ENGAGED IN FOREIGN ECONOMIC ACTIVITY}

Summary. The article examines the problems of motivation of managers of enterprises, engaged in foreign economic activity. The importance of forming an effective motivation system for achieving high results of a foreign economic enterprise is described. The article analyzes the specifics of the functions of managing foreign economic activity and describes ways to implement them for an in-depth understanding of the basic needs of employees, the satisfaction of which is necessary to stimulate the workflow and increase efficiency. Attention is focused on analytical, commodity-production, marketing and sales functions. The basic factors and abilities of personnel needs to perform the tasks of a foreign economic enterprise are described, and their importance for the success of the organization is emphasized. The features and influence of various models and factors, namely material and non-material incentives, the factor of recognition as one of the outstanding measures of motivation of the company's personnel are determined. Ineffective motivation systems and their components are evaluated, possible negative consequences and the ability to cause conflicts are evaluated, and the causes of these factors are determined. The focus is on the main factors of the effectiveness of the motivation system separately. The main measures necessary to improve the effectiveness of the work incentive system are identified and the possible results of their implementation are evaluated. The focus is on monetary incentives for work and its main forms, identified the most effective in the issue of application within a foreign economic enterprise, the provision of additional social security and its possible components as one of the outstanding factors, the interest of employees in performing their work as a priority, achieving this interest in a number of consecutive steps, training and professional development as a means that can benefit both personnel and the enterprise. The Adaptive model is defined as the most effective due to the combination of features of different models. The importance of flexibility and individual approach in the formation of a system of motivation for a foreign economic enterprise is emphasized.

Keywords: motivation, motivation system, foreign economic activity, personnel management, efficiency.

$\Pi^{2}$ остановка проблеми. Мотивація персоналу е важливою проблемою, від ефективності i розв'язання залежить конкурентоспроможність підприемства. Враховуючи велику кількість суб'єктів підприємницької діяльності, система мотивації персоналу впливае не тільки на результати роботи підприемства, але й на успішність у конкуренції за кваліфікованих працівників. Дослідження цього питання необхідне для формування наукової бази створення ефективної системи мотиващії, яка б позитивно впливала на результати господарської діяльності.

Аналіз останніх досліджень і публікацій. Проблематику мотивації менеджерів підприемства, що здійснюе зовнішньоекономічну діяльність досліджували такі вчені як М. Корчун, Е. Свплова, Т. Рибакова та ін. Зокрема, А. Кредісов вивчав проблеми організації управлінської праці, А. Малишев розглядав тему конфліктності в системах мотивації персоналу, Е. Шакір'янова оцінювала ефективність мотиваційних механізмів.

Виділення не вирішених раніше частин загальної проблеми. Не дослідженою залишається проблематика уніфікованої системи мотивації, яка може бути застосована на підприємствах зовнішньоекономічної діяльності різних видів. Необхідно також визначити мотиваційні заходи, які найкраще відповідають специфіці підприемств.

Мета статті полягає у вивченні чинників мотивації менеджерів підприемств, що здійснюють зовнішньоекономічну діяльність.

Виклад основного матеріалу. Питання мотивації персоналу застосовні до будь-якої сфери діяльності і зараз гостро постають перед керівниками зовнішньоекономічних підприемств (ЗЕП). Високих результатів досягають суб’екти господарювання, які у своїй внутрішній політиці 
успішно використовують взаємозв'язок між результатами роботи кожного співробітника і його винагородою, вміло пов'язують загальний результат 3 конкретним внеском окремого члена колективу.

Управління організацією, яка здійснюе зовнішньоекономічну діяльність (ЗЕД), передбачає як загальні управлінські фонкції, притаманні будь-якому виду суб'єктів господарювання, так і специфічні - притаманні саме для ЗЕП. Їх особливість зумовлена предметом та цілями ЗЕД, зокрема:

- аналітична: спрямована на дослідження міжнародного та національних ринків збуту, потреб іноземних споживачів;

- товарно-виробнича: полягає у виготовленні, модернізації, вдосконаленні та адаптації експортних товарів до вимог цільового ринку;

- фрункція збуту: полягае в забезпеченні збуту товарів на цільовому ринку для підвищення едективності продажу товарів;

- маркетингова: відповідає за проведення рекламних кампаній, формування та здійснення цінової політики та інші заходи, спрямовані на збільшення продажів [8].

Виконання таких завдань потребує аналітичних здібностей, інноващійного мислення, лояльності персоналу до підприемства. Від цих чинників залежать: бажання працівника самореалізовуватися у своїй роботі; ефективніше працювати; відати більше зусиль роботі, коли цього вимагає ситуація; досягати цілей. Саме така мотивація забезпечуе синергетичний едект основних складових бізнесу: виробництва та збуту. Такий рівень ефективності веде підприємство до перемоги у боротьбі за споживачів серед місцевих та міжнародних виробників.

Досить часто на ЗЕП система мотивацї не діє з багатьох причин. Серед основних - невпорядкованість (ситуативність) застосування засобів мотивації чи, взагалі, відсутність заохочень. Інколи система мотивації не тільки неефективна, але й може провокувати виникнення конфліктів між працівниками як всередині одного підрозділу, так і підрозділів різних рівнів забезпечення ЗЕД. Такі ситуації можуть виникати внаслідок:

- нечіткого формулювання критеріїв оцінки роботи працівників та їх обов'язків, непоіндормованості персоналу про них;

- призначення на посади працівників, які не володіють відповідними навичками або знаннями для ефективного виконання обов'язків;

- невідповідність системи мотивації чи їі засобів потребам або інтересам персоналу, відсутність індивідуального підходу;

- система мотивації грунтуеться на негативних стимулах, які спричиняють демотивацію, опір та, як наслідок, зниження едрективності праці;

- відсутність гнучкої та оперативної системи оцінки роботи працівників. Внаслідок цього керівники не отримують актуальну інформацію про виконану роботу, а персонал бачить, що їх здобутки не цінують;

- система стимулів не відповідає традиціям чи організаційній культурі персоналу або окремих його членів;

- недостатня цінність стимулів, наприклад, грошова премія, що становить малий відсоток відносно фріксованої або середньої заробітної платні [1, с. 116-120; 5].

Створення ефрективної системи мотивації потребує такої якості як гнучкість. Перш за все, це стосуеться належного обгрунтування набору стимулів та заохочень, які слід визначати на основі інформації про потреби, вимоги та цінності персоналу. Також важливим фрактором є застосування індивідуального підходу, оскільки, цілком ймовірно, різні працівники по-різному реагуватимуть на однакові стимули, а тому їх застосування в окремих випадках не призводитиме до підвищення мотивації [2].

Доцільно виділити дві основні та одну похідну моделі мотивації. Основними моделями є матеріальна та нематеріальна мотивації; мотивація визнанням - $є$ похідною від нематеріальної. Матеріальна модель засновується на застосуванні грошових стимулів (премії, бонуси, надбавки, тощо) та не грошових (оплата мобільного рахунку, подарунки, подорожі тощо). Матеріальну мотивацію доцільно застосовувати як систематично (наприклад, 13-та заробітна плата на рік), так і ситуативно (премія за результати).

Нематеріальна мотивація полягає у створенні сприятливої загальної атмосфери на підприемстві, налагодженні відносин та взаєморозуміння між персоналом та керівництвом. Вона засновується на належному ставленні керівника до підлеглих, поінформованості працівників про їх обов'язки та успіхи компанії, чіткі цілі та плани виконання, регулярне спілкування з персоналом щодо діяльності ЗЕП, тощо. Нематеріальна мотивація хоч і не пов'язана напряму з основною метою роботи (заробітком), але є не менш важливою, оскільки налаштовуе працівників на відповідальне ставлення до роботи.

Мотивація визнанням є однією з найважливіших, оскільки визнання важливості результатів роботи працівника показуе їі важливість для підприемства. Важливо визнавати не тільки результати роботи, але також і професійні знання та навички працівника. Доцільно прислухатися до порад працівників щодо змін на підприемстві, i якщо вони будуть обгрунтованими та доречними - застосовувати їх. Це також покаже персоналу його вагу в організації [3].

Система мотивації підприемства має гнучко комбінувати матеріальні та нематеріальні засоби стимулу, доповнюючи їх мотивацією визнанням. Ця адаптивна система дозволить збалансувати задоволення потреб персоналу відповідно до їх цінностей та зробить їі різноманітною, а також дозволить підтримувати баланс витрат на матеріальну мотивацію [7].

Окремо варто розглянути фрактори ефрективності системи мотивації, які найбільше впливають на покращення роботи підприемства. Серед них:

- грошова винагорода. Змінна частина заробітної плати повинна бути прив'язана до професійних досягнень співробітника і підкреслювати його цінність для компанії. Вона може знаходити вираження у премії за перевиконання плану, відсотку від загального прибутку підприемства (цей інструмент показуе хороші результати мотивації працівників відділу продажів, а тому особливо актуальні для ЗЕП) тощо; 
- соціальний пакет. Власник підприемства може забезпечувати додаткові можливості для покращення повсякденного життя працівників, наприклад: медичне обслуговування в різних клініках, безкоштовне харчування, оплату абонементів або мобільного зв'язку, надання робочого транспорту тощо;

- зацікавленість працівника у виконанні «саме цієї» роботи. Защікавленості робітника можливо досягти комплексом нематеріальних заходів, спрямованих на формування образу важливості досягнення цілей. Основою для цього є комфортна атмосфера, яку слід доповнити регулярними зборами для обговорення проблем робочого процесу, пояснення необхідності виконання тих чи інших обов'язків, реалізації творчих цілей, які викликають зацікавлення у персоналу;

- навчання та підвищення кваліфікації. Додаткове навчання персоналу може бути корисним як для самого працівника, так і для покращення результатів роботи підприемства. Організація загального чи індивідуального навчання може стати додатковим стимулом у разі зацікавлення у ньому персоналу. При цьому доцільно зважувати на рентабельність та форму освіти, регулярність, спрямування тощо $[4 ; 6]$.

Висновки. Сучасне успішне підприемство вимушене конкурувати не лише за споживачів своєї продукції, але і за кваліфікований та ефективний персонал. У зв'язку з цим, систему мотиващії доцільно планувати, зваживши сильні та слабкі сторони працевлаштування у компанії на тлі пропозицій конкурентів. Найефрективнішою видається адаптивна система стимулів, яка містить риси основних моделей мотивації. Застосування тих чи інших засобів мотивації доцільно планувати із урахуванням типових потреб працівників на певній посаді, їх цінності для компанії.

\section{Список літератури:}

1. Авдеева Е.С. Управление системой мотивации сотрудников внешнеэкономических подразделений. Bопросы структуризации эконолики. 2009. № 2.

2. Зайцев Л. Организационное поведение. Москва, 2005. 667 с.

3. Евплова Е. К вопросу о материальной и нематериальной мотивации. Перспективь науки и образования. 2013. C. 104-108.

4. Корчун М.О. Регулювання зайнятості та мотивації праці в умовах ринкової економіки. Социальноэкономические аспекты промышленной политики. Актуальные проблель управления человеческили ресурсали и маркетинга в контексте стратегии развития Украины : Сб. науч. тр. Т. 1. Донецк, 2007. C. 339-344.

5. Малышев А. Антиконфликное мотивирование сотрудников внешнеторговых организаций. Российский внешнеэконолический вестник. 2007. № 1. С. 39-44.

6. Рибакова Т., Амеліна I. Адаптація системи управління персоналом промислового підприемства до умов функціонування на зовнішньому ринку. Управління проектали та розвиток виробництва. 2013. № 3. C. $18-26$.

7. Смірнова Д., Дячек В., Дячек О. Удосконалення системи мотивації персоналу підприемства в умовах розширення зовнішньоекономічної діяльності. Еконоліка та управління підприелствали. 2018. № 16. С. $135-143$.

8. Sycheva N. Motivation in Personnel Management of a Trading Enterprise. International Journal of Economics \& Business Administration (IJEBA). 2019. Vol. Special 1. Pp. 570-582.

\section{References:}

1. Avdeeva E.S. (2009) Upravlenie sistemoj motivacii sotrudnikov vneshnejekonomicheskih podrazdelenij [Managing the motivation system for employees of foreign economic divisions]. Voprosy strukturizacii jekonomiki, no. 2, pp. $44-48$

2. Zajcev L. (2005) Organizacionnoe povedenie [Organizational behavior]. Moskva, $667 \mathrm{p}$.

3. Evplova E. (2013) K voprosu o material'noj i nematerial'noj motivacii [On the issue of material and non-material motivation]. Perspektivi nauki i obrazovanija, pp. 104-108.

4. Rybakova T., Amelina I. (2013) Adaptatsiia systemy upravlinnia personalom promyslovoho pidpryiemstva do umov funktsionuvannia na zovnishnomu rynku [Adaptation of the personnel management system of the industrial enterprise to operating conditions at the foreign market]. Project management and production development, vol. 3 , pp. 18-26.

5. Korchun M. (2007) Rehuliuvannia zainiatosti ta motyvatsii pratsi v umovakh rynkovoi ekonomiky [Regulation of employment and labor motivation in a market economy]. Social'no-jekonomicheskie aspekty promyshlennoj politiki. Aktual'nye problemy upravlenija chelovecheskimi resursami $i$ marketinga $v$ kontekste strategii razvitija Ukrainy, T. 1. Donetsk, pp. 339-344.

6. Malyshev A. (2007) Antikonfliknoe motivirovanie sotrudnikov vneshne-torgovyh organizacij [Adaptation of the Personnel Management System of an industrial enterprise to the conditions of functioning in the foreign market]. Rossijskij vneshnejekonomicheskij vestnik, no. 1, pp. 39-44.

7. Smirnova D., Diachek V., Diachek O. (2018) Udoskonalennia systemy motyvatsii personalu pidpryiemstva v umovakh rozshyrennia zovnishnoekonomichnoi diialnosti [Improvement of the company's personnel motivation system in the context of expanding foreign economic activity]. Ekonomika ta upravlinnia pidpryiemstvamy, no. 16 , pp. $135-143$.

8. Sycheva N. (2019) Motivation in Personnel Management of a Trading Enterprise. International Journal of Economics \& Business Administration (IJEBA), vol. Special 1, pp. 570-582. 